\title{
Multiple cerebral aneurysms originating from previously resected cardiac myxoma
}

\author{
Adilson José Manuel de Oliveira $\square^{1,2}(\mathbb{D})$, Gustavo Correa Lordelo ${ }^{1}$, Saul Almeida da Silva ${ }^{1,3}$, José Guilherme \\ Pereira Caldas ${ }^{3}$, Rhuann Pontes dos Santos Silva ${ }^{4}$, Eberval Gadelha Figueredo ${ }^{1}$
}

\section{ABSTRACT}

Primary cardiac tumors are very rare, accounting for $0,001-0,03 \%$ in autopsy series, cardiac myxoma (CM) account for approximately $50 \%$ of them. Association between $\mathrm{CM}$ and cerebral aneurysm is well documented in this condition but the occurrence of cerebral aneurysm after resection of $\mathrm{CM}$ is very rare, with only 40 reports in medical literature. We present a case of a 45 years old female patient with multiple cerebral aneurysms 2 years after a successful resection of cardiac myxoma, submitted to radiosurgery for 2 bigger aneurysms with good results. This report ads to literature new clinical findings

and a hypothesis of radiosurgery as an effective option of treatment for cerebral aneurysms with origin in $\mathrm{CM}$. Keywords: Cardiac Myxoma; Cerebral aneurysm; Radiosurgery; Neurosurgery.

Keywords: Cardiac Myxoma; Cerebral aneurism; Radiosurgery; Neurosurgery

\section{INTRODUCTION}

Cardiac tumors are rare lesions generally secondary lesions in continuity ${ }^{1}$ or metastatics ${ }^{2}$.Primary cardiac tumors are very rare, accounting for $0,001-0,03 \%$ in autopsy series ${ }^{3}$, cardiac myxoma (CM) account for approximately $50 \%$ of them4. The World Health Organization (WHO) defines CM as a neoplasm composed by stellate to plump, cytologically bland, mesenchymal cells set in a myxoid stroma ${ }^{5}$.

Neurological complications may be the result of thrombus formation, such as intracranial aneurysms, infarcts, hemorrhages, brain metastases and cerebral vascular disorders can be associated with $\mathrm{CM}$. Association between $\mathrm{CM}$ and cerebral aneurysm is well documented on this condition ${ }^{6}$ but delayed cerebral aneurysm formation after resection of $\mathrm{CM}$ is very rare, due only 40 reports in medical literature being the first description in 1894 by Marchand ${ }^{7}$. Anyway, there are no prospective studies or cases with enough follow up to define the natural history, pathogenesis and earlier treatment remains unexplained.

We present a case of a 45 years old female patient with multiple cerebral aneurysms 2 years after a successful resection of cardiac myxoma, submitted to radiosurgery for 2 bigger aneurysms with good results.

\section{CASE REPORT}

A 45 years old woman with 2 months of history of progressive dyspnea, initially for moderate efforts and at time of admission at hospital was for small efforts as daily routine activities. The medical history reveals childhood poliomyelitis with flaccid right upper limb monoplegia, no other relevant information.

The cardiac examination reveals a grade III apical murmur with no other relevant findings, neurological examination

1- Vascular Neurosurgery, Hospital das Clínicas, Faculdade de Medicina da Universidade de São Paulo, SP - Brazil. Orcid: 0000-0001-6104-569X

2- Neurosurgery Service, Clínica Girassol, Luanda, Angola

3- Endovascular Group, Hospital das Clinicas da Faculdade de Medicina da Universidade de São Paulo, SP - Brazil

4- Catholic University of Pernambuco, Recife, PE - Brazil

$\triangle$ - Autor correspondente. Email: adilsonvalmont@gmail.com

DOI: https://doi.org/10.54283/RACSaude.v2n2.2021.p10-13

Recebido: 03 de Maio de 2021 / Aceite: 06 de Junho de 2021 / Publicado: 30 de Junho de 2021 
was normal except for the previous sequel monoplegia in the right upper limb. Vascular study was not done at that juncture, but echocardiogram reveals in left atrium a oval mass, pedunculated, adhered to the interatrial septum measuring $3.4 \times 3.6 \mathrm{~cm}$ (Figure 1).

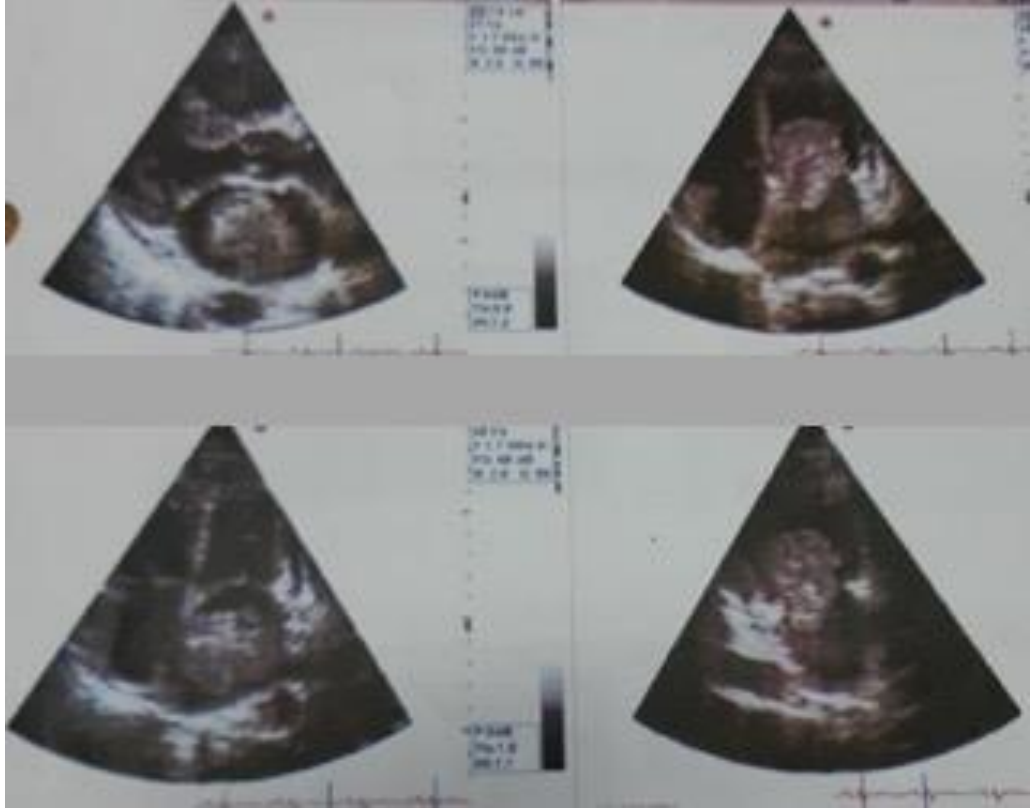

Figure 1 - Initial echocardiogram reveals in left atrium a oval mass, pedunculated, adhered to the interatrial septum measuring $3.4 \times 3.6 \mathrm{~cm}$.

Surgical resection was performed with complete resection and without postoperative complications, the patient was discharged from the hospital a few weeks later asymptomatic.

Two years later de patients complains of multiple episodes of tonic - clonic seizure, radiologic investigation with $C T$ and MRI reveals multiples lesions suggestive of fusiform aneurysms (Figure 2A-2B, diagnostic was confirmed by digital subtraction angiography (DSA) showing multiples distal small fusiform aneurysm four aneurysms of middle cerebral artery M4 segment been the two largest lesions frontal and parietal 7 and $5 \mathrm{~mm}$ (figure 2C-D). The patient was submitted to radiosurgery with a single dose of 12 Gray in both lesions.

Seizures was clinically controlled using valproic acid $500 \mathrm{mg}$ twice a day.

One-year DSA reveals control of the two irradiate lesions and new smalls and distal fusiform lesions (Fig. $2 \mathrm{E}$ F).

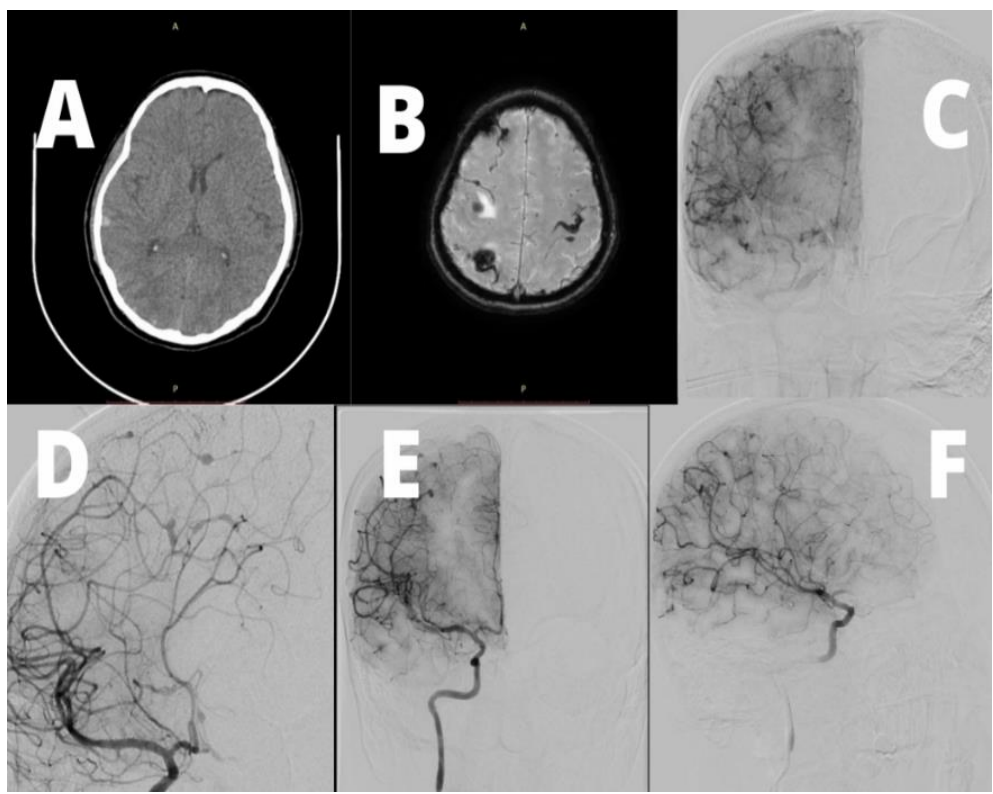

Figure 2-CT and MRI reveals multiples lesions suggestive of fusiform aneurisms (A) and (B), respectively. Digital substration angiography (DSA) showing multiples distal small fusiform aneurysm four aneurysms of middle cerebral artery M4 segment been the two largest lesions frontal and parietal 7 and $5 \mathrm{~mm}$. (C) (D) One-year DSA reveals control of the two irradiate lesions and new smalls and distal fusiform lesions (E) (F). 
At this time with almost 3 years of follow up the patient is asymptomatic (cardiologic and neurologic), scheduled for new angiography follow up in a year.

\section{DISCUSSION}

Acute neurological complications of cardiac myxomas as stroke or aneurysm formation are well described but delayed complications particularly fusiform aneurysms are very limited.

The present case has both common and uncommon characteristics compared with previously described. Female patients are $71 \%$ of previously described, CM is in the left atrium in $91 \%$ and almost all aneurysms were fusiform (91\%) these characteristics are compatible with our case8. On the other hand we present a case with some news aspects in clinical presentation, that may help the medical community to perform diagnosis.

The formation of aneurysms after the resection of cardiac myxoma is unclear. The tumor cells in the embolism lead to perivascular damage, the inflammatory response at the site of injury and the deposition of the tumor into the vasa vasorum were proposed hypotheses to explain the mechanism why there is progression of aneurysms despite the surgery.

The endocrine and secretory properties of $\mathrm{CM}$ cells support the tumor emboli deposition in the vessel wall. A 23- year-old patient who presented with multiple cerebellar hemorrhages presented high levels of IL-6 in the CSF. These IL- 6 levels returned to normal after resection of the CM and they have thus suggested these interleukines as a marker for neurological manifestations.

Dyspnoea as initial isolated symptom of CM without constitutional symptoms was not previously described and this can be a differential diagnosis of progressive dyspnea that can confirmed or ruled out by a inexpensive, non invasive and fast exam - Echocardiogram ${ }^{9}$, that can show a pedunculated lesion occupying all left atrium as previous biopsy shows ${ }^{10}$. The neurological symptom of this case (seizure) is also a new feature, previously described neurological symptoms migraine like headache, motor strength deficits and conscious level alteration ${ }^{7}$.

Treatments of cerebral aneurysm secondary to $\mathrm{CM}$ are not well defined. The conservative management is the preferred choice. However, the finding that dividing tumor cells are responsible for aneurysm formation suggests the possibility of using chemotherapy to prevent aneurysmal growth, but the results of doxorubicin alone are equivocal ${ }^{10}$. Low-dose radiation therapy alone or in conjunction with chemotherapy revealed more encouraging results $^{12,13}$. Cardiac surgery to remove the primary cardiac tumors usually eliminates early neurologic symptoms, but cannot completely abolish the risk of delayed cerebral aneurysm formation, presumably as a result of metastatic seeding prior to surgery ${ }^{11}$. There are no randomized controlled trials to address this issue.

We present a case that only two years later the patient presents multiple episodes of tonic - clonic seizure after the CM resection. Recurrent embolic strokes with later evaluation revealed multiple cerebral aneurysms secondary to a cardiac myxoma detected 10 and 25 years, respectively, as reported in the literature. Despite treatment of cardiac myxoma, intracranial complications can have delayed presentation. Our case is in keeping with the current literature of the preferential distribution to the MCA territory as compared to the vertebrobasilar circulation.

\section{CONCLUSION}

$\mathrm{CM}$ are very rare lesions and association with cerebral aneurysms are even rarer. We present a case of a 45 years old female patient with multiple cerebral aneurysms 2 years after a successful resection of cardiac myxoma, submitted to radiosurgery for 2 bigger aneurysms with good results.

This report adds to literature new clinical findings and a hypothesis of radiosurgery as an effective option of treatment for cerebral aneurysms with origin in CM. However, randomized controlled trials are essential to address this issue and guide therapeutic approach. On the other hand, non-invasive evaluation of the cerebral arteries should be done on a regular basis to detect the presence of delayed formation of intracranial aneurysms after the resection of the $\mathrm{CM}$. This is due to the new findings about cerebral vessel involvement with intracranial deposition in cardiac myxomas.

\section{Limitações do estudo}

Este estudo tem várias limitações. A mais importante delas é o reduzido tamanho da amosta (29 doentes). É, portanto, imperativo que mais estudos sejam realizados para melhor caracterizar o perfil radiológico dos pacientes com doença de Pott. 


\section{Protecção de pessoas e animais}

Os autores declaram que os procedimentos estavam de acordo com os regulamentos estabelecidos pelos responsáveis da Comissão de Investigação Clínica e Ética e de acordo com a Declaração de Helsínquia da Associação Médica Mundial actualizada em 2013.

\section{Confidencialidade dos dados}

Os autores declaram ter seguido os protocolos do seu centro de trabalho acerca da publicação de dados.

\section{Conflito de interesse}

Os autores afirmam não haver conflito de interesse relacionados com a presente pesquisa.

\section{Fontes de Financiamento}

Esta pesquisa não recebeu qualquer tipo de suporte financeiro.

\section{REFERÊNCIAS BIBLIOGRÁFICAS}

1. Aiello VD, Tanigawa RY, Chate RC, de Campos FP, Mansur AJ. Progressive dyspnea and a right atrial mass in an 80-year-old man. Autopsy \& Case Reports. 2019 Oct;9(4). doi: https://dx.doi.org/10.4322\%2Facr.2019.135

2. Manuel V, Dinato FJ, Gutierrez PS, Siqueira SA, Gaiotto FA, Jatene FB. Cardiac metastatic endometrial stromal sarcoma 17 years after hysterectomy. Journal of cardiac surgery. 2017 Oct;32(10):636-8. doi: https://doi.org/10.1111/jocs.13221

3. Straus R, Merliss R. Primary tumor of the heart. Arch Pathol (Chic). 1945;39:74.

4. Silverman NA. Primary cardiac tumors. Ann Surg .1980; 191 ( 2 ) : 127 - 38 . doi: http://dx.doi. org/10.1097/00000658-198002000-00001. PMid:7362282.

5. Burke AP, Tazelar H, Gomez-Roman JJ, Loire R, et al. World Health Organization: tumours of the lung, pleura, thymus and heart. Lyon: IARC Press; 2004.

6. Reynen K. Cardiac myxomas. New England Journal of Medicine. 1995 Dec 14;333(24):1610. doi: http://dx.doi. org/10.1056/NEJM199512143332407

7. Marchand F. Zurkenntnis der embolie und thrombose der gerhirnarterien, zugleicheinbeitragzurcasuistik der primarenherztumoren und der gekreuztenembolie. KlinWochenschr. 1894;31(1):e5.

8. Sabolek M, Bachus-Banaschak K, Bachus R, Arnold G, Storch A. Multiple cerebral aneurysms as delayed complication of left cardiac myxoma: a case report and review. Acta Neurologica Scandinavica. 2005 Jun;111(6):345-50. doi: https://doi.org/10.1111/j.1600-0404.2005.00413.x

9. Goswami KC, Shrivastava S, Bahl VK, Saxena A, Manchanda SC, Wasir HS. Cardiac myxomas: clinical and echocardiographic profile. International journal of cardiology. 1998 Feb 28;63(3):251-9. doi: https://doi.org/10.1016/S0167-5273(97)00316-1

10. Aiello VD, de Campos FP. Cardiac myxoma. Autopsy and Case Reports. 2016 Jun 11;6(2):5. doi: http://dx.doi.org/10.4322/acr.2016.030

11. Roeltgen DP, Weimer GR, Patterson LF. Delayed neurologic complications of left atrial myxoma. Neurology. 1981 Jan 1;31(1):8. doi: https://doi.org/10.1212/WNL.31.1.8

12. Bernet F, Stulz PM, Carrel TP. Long-term remission after resection, chemotherapy, and irradiation of a metastatic myxoma. The Annals of thoracic surgery. 1998 Nov 1;66(5):1791-2. doi: https://doi.org/10.1016/S0003-4975(98)00917-5

13. Damasio H, Seabra-Gomes R, Da Silva JP, Damasio AR, Antunes JL. Multiple cerebral aneurysms and cardiac myxoma. Archives of neurology. 1975 Apr 1;32(4):269-70. doi: http://dx.doi. org/10.1001/archneur.1975.00490460085013 